Prace Filologiczne. Literaturoznawstwo 11(14) 2021

ISSN 2084-6045

e-ISSN 2658-2503

Creative Commons: Uznanie autorstwa 3.0 PL (CC BY)

DOI: $10.32798 /$ pflit.621

\title{
PROGI I MOSTY. KOD TEMPORALNY W HISTORIACH LITERATURY
}

\author{
Thresholds and Bridges. Temporal Code in Histories of Literature
}

\author{
EWA PACZOSKA \\ Uniwersytet Warszawski, Polska \\ E-mail: e.paczoska@uw.edu.pl \\ https://orcid.org/0000-0001-6815-2359
}

\begin{abstract}
For the past two decades historians as well as literary historians have been manifesting a symptomatic distrust of time marks as clear ordering categories, it is therefore worth regarding them as the adjunctive and not fundamental markers of literary and cultural changes. Based on various examples, the article proves that time-related categories are closely related to literature and the dynamics of its course of events but the comprehensive rationale that lies behind the application of these categories depends on a number of factors including the sense of temporality that influences thresholds of literary experiences or the impact of network reality on changes in literature. Hence, according to the author of this article, the concept of adequacy of time marks in historical and literary practice is best described by the metaphor of a bridge.
\end{abstract}

Keywords: time marks, temporal code, Modernism, 1989, history of literature

\section{Streszczenie}

W badaniach historyków i badaczy dziejów literatury widać w ostatnich dwóch dekadach charakterystyczną nieufność wobec cezur jako wyrazistych kategorii porządkujących, dlatego traktować je warto jako pomocnicze, a nie podstawowe wyznaczniki literackich i kulturowych przemian. W artykule na różnych przykładach dowiedziono, że kategorie temporalne są ściśle związane z literaturą i dynamiką zdarzeń życia literackiego, ale sens ich stosowania zależy od wielu czynników (tak różnych jak poczucie czasowości wpływające na progi pisarskich doświadczeń czy wpływ sieciowej rzeczywistości na zmiany w literaturze). Toteż, zdaniem autorki, wyobrażenie funkcjonalności kategorii granicznych w praktyce historycznoliterackiej najlepiej określa metafora mostu.

Słowa kluczowe: cezury, kod temporalny, modernizm, 1989, historia literatury 


\section{Cezury na cenzurowanym}

Pytanie o funkcjonalność kategorii cezury w badaniach literackich ma integralny związek z innymi pytaniami - przede wszystkim tymi o sens historii literatury, o jej procedury i metody, a nawet wręcz o wyznaczniki jej naukowej tożsamości. Jeśli chodzi o rozpoznania polskich badaczy, to dyskusjom na ten temat wciąż patronuje projekt nazwany przed laty przez Teresę Walas „inną historią literatury”. Inną - tzn. nakierowaną na splot różnych „historyj”, rezygnującą z uroszczeń obiektywizmu i absolutyzowania wagi dziejowych momentów uznawanych dotąd za kulminacyjne, otwartą na opowieści lokalne, często te wyparte z kanonu czy przezeń unieważniane, podążającą szlakiem „mikrohistorii”, jak to nazywa Ewa Domańska², czy, wedle określenia Walas, „niebyłej historii literatury”3. Projekt ten, na którego kształt wpłynęły koncepcje, z jednej strony, Haydena White'a, a z drugiej badaczy z kręgu poststrukturalizmu i dekonstrukcjonizmu, wyznaczył w pewien sposób szlaki kulturowej historii literatury w Polsce. Jej kariera (ale i w ogóle znaczenie we współczesnej humanistyce) związane są z narastaniem, jak to określił kiedyś Tomasz Kunz, świadomości wagi porządku „»kulturalnego « - a więc nie apriorycznie danego, ale każdorazowo kształtowanego czy też wytwarzanego w wieloaspektowo zrelatywizowanym akcie poznania"4.

Nieprzystawalność dynamiczności i wieloaspektowości rozpoznawanej w ten sposób kultury do wizji historii literatury polskiej jako komody z wyraziście oddzielonymi od siebie szufladami epok wskazywali od dawna różni badacze. Wielu z nich, np. zajmujących się bliskim mi wiekiem XIX, od dawna kierowało swoją uwagę ku meandrom „międzyepok”, dekad badawczo zaniedbanych, ukrytych w cieniu stereotypów lektury związanych zawsze w jakiś sposób z wyrazistością tradycyjnie pojmowanych cezur ${ }^{5}$. Nie jest przypadkiem, że autorzy ci,

${ }^{1}$ T. Walas, Czy jest możliwa inna historia literatury?, Kraków 1993. Vide również: „Inna historia literatury jest możliwa”. Rozmowa z Teresa Walas przeprowadzona przez Agnieszkę Wnuk i Tomasza Mackiewicza, „Tekstualia” 2010, nr 3.

${ }^{2}$ Vide E. Domańska, Mikrohistorie. Spotkania w międzyświatach, Poznań 1999.

${ }^{3}$ Vide T. Walas, „Niebyła” historia literatury, w: Narracja i tożsamość, t. 2: Antropologiczne problemy literatury, red. R. Nycz, W. Bolecki, Warszawa 2004.

${ }^{4}$ T. Kunz, Nowa historia literatury - bez dogmatu i bez przedmiotu?, „Ruch Literacki” 2011, z. 6 , s. 53 .

${ }^{5}$ Warto tu przypomnieć choćby kanoniczne już rozpoznania Janusza Maciejewskiego (Przedburzowcy. Z problematyki przełomu między romantyzm a pozytywizmem, Kraków 1973), Ryszarda Przybylskiego (Klasycyzm, czyli prawdziwy koniec Królestwa Polskiego, Warszawa 1983), artykuły Marii Żmigrodzkiej na temat polskiego biedermeieru (m.in. Polska powieść biedermeierowska, „Pamiętnik Literacki” 1966, z. 2), Mariana Płacheckiego o „dekadentyzmie południa wieku” (Dekadentyzm południa wieku: rekonesans, „Studia Filologiczne Akademii Świętokrzyskiej” 2002, t. 17), których tropem idzie wielu badaczy następnych pokoleń. Z ostatnio wydanych pozycji warto choćby wspomnieć tom Literatura i kultura lat 60. XIX wieku między polityka a prywatnościa. Dyslokacje, red. U. Kowalczuk, D. Makuch, D. Osiński, Warszawa 2019. 
jak np. Janusz Maciejewski, proponowali zastąpienie pojęcia epoki literackiej kategorią formacji intelektualnej czy formacji literackiej, która pozwalała ominąć pułapki wynikające z kategorii „międzyepoki” czy „pisarzy osobnych”6.

Kulturowa historia literatury, a także w różny sposób związane z nią: krytyka feministyczna, regionalistyka, badania spod znaku „gender” czy rozpoznania „tekstowego świata”, postawiły zatem kategorię cezury na cenzurowanym. Przede wszystkim dlatego, że pokazały niebezpieczną arbitralność cezur, służącą odcinaniu czy zagłuszaniu różnorodnych opowieści o doświadczeniu, które przede wszystkim chce zgłębiać dzisiejsza humanistyka. Ma to także związek z sytuacją syntezy, która ustąpiła miejsca innym gatunkom wypowiedzi historycznoliterackiej (do sprawy tej jeszcze powrócę). Obok kariery „case studies” trzeba tu wspomnieć o pojawieniu się form luźnych, amorficznych, zbudowanych w opozycji wobec syntezy wykorzystującej wyraziste granice czasowe strukturyzujące dzieje piśmiennictwa. Do takich nowych form należą, jak przekonuje Joanna Maj, np. turystyczny przewodnik literacki, rozmowa, dziennik. Wszystkie je łączy, jak stwierdza autorka, wybór kompletnie innowacyjnego modelu narracji: „Nowe historie literatury odrzucają totalizujący sposób opowieści [...]. Proces literacki nie stanowi w ich ujęciu całościowego czy celościowego zjawiska - bywa, że pojęcie »procesu literackiego « wcale nie funkcjonuje w nowych historiach literatury. Zamiast uniwersalności interesuje indywidualność, to, co pojedyncze, unikatowe"7.

Przemiany polskiej historii literatury w ostatnich dekadach wiązały się także bez wątpienia z chęcią wyzwolenia kultury, zwłaszcza naszej, spod presji perspektywy narodowocentrycznej. ${ }^{8}$. Charakterystyczne, że o tej presji dużo na początku XXI w. mówili też historycy, zauważając, jak Andrzej Chwalba, iż „społeczne i narodowe oczekiwania przesądziły o tematyce i klimacie polskiego dyskursu historiograficznego", co nie tylko ograniczyło krąg badawczych poszukiwań, ale także, w pewnym stopniu, skazało te poszukiwania na naukową izolację w Europie czy świecie. Efektem zaś był „koturnowy, a z pewnością wyidealizowany obraz naszych narodowych dziejów, przy tym obraz pozbawiony wielu istotnych aspektów, np. tych ściśle związanych z wewnętrznym doświadczeniem romantyków"10. Autor tak konstatował owoce tego dyskursu w kontekście własnego

${ }^{6}$ Vide J. Maciejewski, Miejsce pozytywizmu polskiego w XIX-wiecznej formacji kulturowej, w: Pozytywizm. Języki epoki, red. G. Borkowska, J. Maciejewski, Warszawa 2001.

${ }^{7}$ J. Maj, Nowe historie literatury polskiej - metodologiczny rekonesans, w: Polonistyka na początku XXI wieku. Diagnozy, koncepcje, perspektywy. Materiały VI Światowego Kongresu Polonistów, Katowice 2016, s. 289.

${ }^{8}$ Vide G. Borkowska, O historii literatury polskiej w kontekście nie tylko polskim. Kilka pytań, co nie nowe, w: ibidem, s. 284.

${ }^{9}$ A. Chwalba, Metodologiczne aspekty badań nad historia Polski w XIX wieku, „PAU. Prace Komisji Historii Nauki” 2004, t. 6, s. 81.

${ }^{10}$ Ibidem. 
przedmiotu - czyli dziejów wieku XIX: „Dalej zatem niewiele wiemy o tym, jak przebiegały podstawowe procesy kulturowe, cywilizacyjne i etniczne na naszych ziemiach pod zaborami"11. Jednym ze źródeł tej niewiedzy było na pewno podkreślanie $\mathrm{w}$ tradycyjnym dyskursie rodzimej historiografii tych wydarzeń, które służyły jako znaki kodu patriotycznego. Wiązało się to z dominacją modeli literatury ukształtowanych w kręgu Wielkiej Emigracji i wynikającym stąd niedoszacowaniem zjawisk krajowych. Organizowanie rodzimej przeszłości wedle cezur heroizujących „polski czyn” to obraz wciąż w społecznym odbiorze z różnych względów atrakcyjny - co widać zarówno w dzisiejszym dyskursie publicznym, jak i w wyborach tożsamościowych pewnych środowisk czy grup.

W badaniach historyków i badaczy dziejów literatury widać zatem w ostatnich dwóch dekadach charakterystyczną nieufność wobec cezury jako wyrazistej kategorii porządkującej. Ma to związek, jak już wspominałam, m.in. z nakierowaniem uwagi na indywidualne przeżywanie historii wpisujące się $\mathrm{w}$ porządek pojedynczych biografii, na perspektywę „mikro”. Ta perspektywa łączy się na wielu poziomach z inspiracją geopoetyki i „zwrotem przestrzennym” w badaniach kulturowych. Rację przyznać trzeba Grażynie Borkowskiej, która pisze, że „dzisiejsze koncepcje historycznoliterackie są raczej przestrzenne, tematyczne (literatura pogranicza, literatura chłopska, literatura kobieca) niż temporalne, wyraźniej skupione na rozróżnieniach innych niż czasowe" ${ }^{12}$.

\section{Uzgadnianie. Mapa modernizmu}

Tradycyjne dyskursy polskiej historiografii i historii literatury nie tylko wybierały doświadczenie zbiorowe na niekorzyść indywidualnego. Cytowany przeze mnie wyżej Andrzej Chwalba, diagnozując zaniechania polskiej historiografii, podkreślał, że niektóre z przyjętych przez nią wewnętrznych dziejowych cezur trudno czasem było uzgodnić z tymi, które ustaliły się w nauce europejskiej. Także przywiązanie historyków literatury do kalendarza ważnych dla Polaków dziejowych dat i określonej wizji naszej kultury utrudniało wpisanie jej w rytmy rozwojowe europejskie i światowe. Jeśli chodzi np. o wiek XIX, trwający oczywiście co najmniej kilkanaście lat dłużej, to, jak wiadomo, przez wiele lat pokutował w historii literatury obraz „wielkiego stulecia Polaków” (żeby przywołać tytułowe określenie z książki Aliny Witkowskiej ${ }^{13}$ ) stworzony wedle scenariusza, w którym główne role przeznaczono dla romantyków z kręgu Wielkiej Emigracji. Stąd przede wszystkim wynikały kłopoty z tzw. epoką pozytywizmu, precyzyjnie wyróżnianą w dziejach naszego piśmiennictwa - inaczej niż działo się to

\footnotetext{
${ }^{11}$ Ibidem, s. 82.

${ }^{12}$ G. Borkowska, op. cit., s. 284 (podkr. - aut.).

${ }^{13}$ A. Witkowska, Wielkie stulecie Polaków, Warszawa 1987.
} 
we francuskich czy angielskich historiach literatury. Dopiero wprowadzenie kategorii „dziewiętnastowieczności” czy pojęcia „dziewiętnastowiecznej formacji kulturowej” pozwoliło zobaczyć kulturę tamtego stulecia jako całość o wyraźnych dominantach i wewnętrznych cezurach ${ }^{14}-$ tak, jak widzieli ją i widzą historycy zachodni.

Uzgodnieniu polskiego obrazu XIX w. z dziejami kultury Europy posłużyła też na pewno dyskusja o modernizmie, którą przyniósł postmodernizm. Pod koniec lat osiemdziesiątych Giorgio Agamben tak np. określał znaczenie dojrzałego modernizmu dla kultury całego XX w.: „To zdumiewające, że garstka pisanych w latach 1915-1930 dzieł literatury i filozofii nadal w sposób niezachwiany dzierży klucz do nastroju epoki, że ostatni przekonywający opis naszych uczuć, naszego stanu ducha pochodzi zatem sprzed co najmniej pięćdziesięciu lat [...]. Nie oznacza to, że odtąd nie powstawały już wartościowe dzieła ani w literaturze, ani w filozofii: rzecz w tym, że nie zawarły w sobie inwentarza nowych uczuć epoki”" ${ }^{15}$. Sprawa „modernizmów i ich losów” 16 w polskich badaniach historycznoliterackich ma już potężną literaturę przedmiotu, do której nie chcę tutaj wracać. Wprowadziła ona perspektywę „modernizmu sensu largo”, która wykreśliła nowe wektory rozwoju literatury polskiej w wiekach XIX i XX. Związana z wykorzystaniem tej perspektywy teza Ryszarda Nycza o „modernistycznej formacji literackiej" jako fundamencie polskiej literatury wieku $\mathrm{XX}^{17}$ oraz badania Włodzimierza Boleckiego ${ }^{18}$ udowodniły słabość tradycyjnie wyznaczanych granic epoki Młodej Polski i wzięły je w nawias.

W istocie trudno dziś serio traktować zwłaszcza rok 1890 (w tradycyjnych syntezach początek epoki) jako cezurę historycznoliteracką - co nie znaczy, niestety, że nie jest ona ciągle tak stosowana, do czego jeszcze powrócę. Nie można bowiem znaleźć dla niej argumentów po stronie twórczości ani tzw. pozytywistów, ani tzw. młodopolan. Patrząc na tych pierwszych, dziś coraz lepiej uświadamiamy sobie ich związek nie tylko z „dziewiętnastowiecznością”, o czym była już mowa, ale także - $\mathrm{z}$ nowoczesnością i szeroko pojmowanym

${ }^{14}$ Vide J. Maciejewski, Miejsce pozytywizmu polskiego w XIX-wiecznej formacji kulturowej oraz A. Kowalczykowa, Wiek XIX: przetomy, cezury, płynność, w: Wiedza o literaturze i edukacja. Ksiega referatów Zjazdu Polonistów Warszawa 1995, red. T. Michałowska, Z. Goliński, Z. Jarosiński, Warszawa 1996.

${ }^{15}$ G. Agamben, Idea prozy, tłum. i posłowie E. Górniak-Morgan, komentarz A. Serafin, Warszawa 2018, s. 101.

${ }^{16}$ To formuła Tomasza Majewskiego, vide idem: Modernizmy i ich losy, w: Rekonfiguracje modernizmu. Nowoczesność i kultura popularna, red. idem, Warszawa 2009.

${ }^{17}$ R. Nycz, Język modernizmu. Prolegomena historycznoliterackie, Warszawa 1997. Vide E. Paczoska, Słowo wstępne, w: eadem, Prawdziwy koniec XIX wieku. Śladami nowoczesności, Warszawa 2010 oraz Tomasz Cieślak-Sokołowski, Nowe modernizmy. Mapa debat, „Poznańskie Studia Polonistyczne”, Seria Literacka 24 (44): Odnawianie modernizmu, Poznań 2014, s. 13-34.

${ }^{18}$ W. Bolecki, Modalności modernizmu. Studia, analizy, interpretacje, Warszawa 2012. 
modernizmem ${ }^{19}$. A polską nowoczesność i pierwsze modernistyczne odpowiedzi na jej wyzwania datować można oczywiście dużo wcześniej. Także w rozwoju twórczości pokolenia Młodej Polski rok 1890 jest datą słabą (o wiele np. słabszą niż pierwsza dekada nowego stulecia z rewolucyjnym, także dla literatury, rokiem 1905!).

Oczywiście nie chodzi tu o to, by wyrugować z historii literatury polskiej historyczne zjawiska sygnowane nazwami „pozytywizmu” i „Młodej Polski”. Zdaję sobie też sprawę z niebezpieczeństw uproszczonego „modernizowania” twórczości pisarzy drugiej połowy XIX i początków XX w. Rację bowiem ma Agnieszka Kluba, kiedy pisze, że „w imię [...] wewnętrznej logiki literatury należy uważać, aby nagle odkrywana »dwudziestowieczność« Młodej Polski nie zaczęła przesłaniać lub wręcz odcinać jej dziewiętnastowiecznych korzeni”" ${ }^{20}$. Zgadzam się też z jej opinią, że „tylko ujawnienie powikłań cechujących "przygotowawczy« etap Młodej Polski pozwoli ocenić następujące po niej przemiany światopoglądowo-estetyczne, które zadecydowały o charakterze rodzimego, szeroko rozumianego modernizmu"21. Chodzi jednak o to, byśmy, świadomi tych „powikłań”, zdawali sobie jednocześnie sprawę z problematyczności pojęcia epoki i nie traktowali wyznaczających je cezur (związanych np. z wystąpieniami programowymi) jako progów o przełomowym dla literatury znaczeniu. Absolutyzowanie tworzonych na ich podstawie cezur mistyfikuje obraz przemian myśli, odczucia rzeczywistości i wyobraźni, których gra składa się na literaturę.

Jak wiadomo, nazwa „Młoda Polska” w słowniku samych jej twórców była w istocie rodzajem, jak to określa Kluba, „wymijającej etykietki”, używanej przez wstępujących w życie, co wskazuje na „nieumiejętność wyróżnienia jednej dominującej cechy"22 całkiem nowej wedle ich deklaracji epoki. Charakterystyczne, że podobnie zastępczy charakter miał dla twórców literatury postyczniowej termin „pozytywizm”, przyjęty, jak sami mówili, jako rodzaj „nom de guerre” - z braku lepszych ${ }^{23}$. To ważne podpowiedzi ze środka XIX w., potwierdzające teze, że obraz nowoczesnych przemian (z powodu ich wszechstronnego charakteru i tempa) nie da się uzgodnić z koncepcją epoki o wyraźnie wyznaczonych cezurach. Należy je widzieć raczej jako punkty jedne $\mathrm{z}$ wielu na mapie konstruowanej z zastosowaniem zróżnicowanych kryteriów - zarówno wewnątrz- jak i zewnątrzliterackich. Należy tu jeszcze dodać, w końcu najbardziej charakterystyczne

${ }^{19}$ Vide M. Gloger, Pozytywizm: między nowoczesnościa a modernizmem, „Pamiętnik Literacki” 2007, z. 1. (Nawiasem mówiąc, szkoda, że tych bliskich związków nie widzą często badacze literatury pierwszych dekad XX w., tacy jak np. wspominany wyżej Nycz).

${ }^{20}$ A. Kluba, Autoteliczność - referencyjność - niewyrażalność. O nowoczesnej poezji polskiej (1918-1939), Wrocław 2004, s. 25.

${ }^{21}$ Ibidem, s. 27.

${ }^{22}$ Ibidem, s. 26.

${ }^{23}$ Vide P. Chmielowski, Zarys literatury polskiej z ostatnich lat szesnastu, Wilno 1881, s. 65. 
dla rysowania mapy, uwarunkowania geograficzne. Bo jeśli np. w oczach pewnego środowiska artystów krakowskich rok 1890 mógł w istocie oznaczać nowe otwarcie, to na pewno nie miał takiego charakteru dla pisarzy z Warszawy czy Lwowa. A to właśnie, jak sądzę, wielośrodowiskowość w decydujący sposób określa twórczość polskich modernistów przełomu XIX i XX w. ${ }^{24}$ Dziś, gdy chętniej mówimy o „modernizmach” niż o modernizmie ${ }^{25}$, zwracając uwagę na różne warianty i odmiany lokalne, trudno w badaniach literatury drugiej połowy XIX i XX w. zamykać się w przestrzeni wyznaczanej przez ogrodzenia tradycyjnych cezur. Traktować warto je, powtórzmy, jako pomocnicze, a nie podstawowe wyznaczniki literackich i kulturowych przemian. No i oczywiście wciąż szukać nowych, przede wszystkich tych wywiedzionych z doświadczeń pisarzy danego czasu.

\section{Odczucie czasowości}

Od jakichś cezur historyk literatury nie może bowiem uciec, bo kategorie temporalne są ściśle związane z literaturą i dynamiką zdarzeń życia literackiego, które decydują o kształcie „świata literackości”, obejmującego pisarzy i czytelników. Danuta Sosnowska, podkreślając, jak ważna w badaniach kulturowych i literaturoznawczych jest perspektywa temporalna, stwierdza, że trzeba „brać pod uwagę wpływ wywierany przez tę temporalność na odczuwanie tożsamości i identyfikacyjną wrażliwość"26, a więc przede wszystkim - odczucie czasowości charakterystyczne dla pisarzy i generacji, do których oni przynależą ${ }^{27}$. To od dawna zresztą przedmiot badań socjologów, analizujących, jak np. Elżbieta Tarkowska, świadomość temporalną Polaków. W swojej książce, wydanej niedługo po transformacji 1989 r., refleksji poddaje takie kwestie, jak pamięć społeczna, dziedzictwo kulturowe czy pokoleniowa mentalność temporalna ${ }^{28}$.

Pytając o sens historycznoliterackich cezur, warto zatem przede wszystkim wykorzystywać podpowiedzi pisarzy - i to raczej nie te, które manifestują oni w tekstach o charakterze programowym. Ale zacznijmy właśnie od tych ostatnich, bo w nich często wyznacza się granice, których tropem nierzadko idą później historycy literatury. Wyznaczanie wyrazistej cezury jest przede wszystkim

${ }^{24}$ Więcej na ten temat: E. Paczoska, Młoda Polska i mapy modernizmu, w: Młoda Polska w najnowszych badaniach, red. E. Jakiel, T. Linkner, Gdańsk 2016, s. 11-22.

${ }^{25}$ Vide E. Paczoska, Wstęp, w: Problemy literatury i kultury modernizmu w Europie Środkowo-Wschodniej, t. 1: Teksty doświadczenia, red. E. Paczoska, I. Poniatowska, M. Chmurski, Warszawa 2017.

${ }^{26}$ D. Sosnowska, Czeski przełom modernistyczny a kondensacja czasu kulturowego, „Przegląd Filozoficzno-Literacki” 2013, nr 1-2: Modernizm(y) Europy Środkowo-Wschodniej, s. 287.

${ }^{27} \mathrm{Na}$ pewno ważne jest też odczucie czasowości historyków literatury - np. wtedy, gdy przeżywana intensywnie zmiana każe im szukać równie wyrazistych progów w obszarze własnych badań. Tak się składa, że piszę ten tekst w okresie izolacji wprowadzonej w związku z pandemią. Moje własne odczucie czasowości na pewno łączy się z tym doświadczeniem.

${ }^{28}$ E. Tarkowska, Czas w życiu Polaków: wyniki badań, hipotezy, impresje, Warszawa 1992. 
potrzebne młodym wstępującym na scenę literatury, którzy pragną swoje wejście opromienić fajerwerkiem wielkiej zmiany. To oni chętnie mówią, żeby zacytować Aleksandra Świętochowskiego, o „popalonych mostach i zerwanych groblach”29 między sobą a odsyłanym do lamusa starszym pokoleniem. Wystąpienia te jednak jako wyznacznik literackiego progu historyk literatury powinien traktować z ostrożnością, pamiętając o strategiach wynikających z poetyki manifestu jako gatunku ${ }^{30}$. Często też łączą się one $\mathrm{z}$ autodeklaracjami o charakterze politycznym (,już dość!”, „teraz my!”), które w wielu przypadkach wzmocnić mają wyrazistość wyznaczanej z ich punktu widzenia cezury. $\mathrm{Z}$ tego względu zatem nie może nas zadowolić „,wariant historycznoliterackiej koncepcji okresu wyprowadzony z charakterystyki jego fazy wstępnej”" ${ }^{31}$, bazującej tak często na analizie wystąień programowych ${ }^{32}$.

Ale formuła głosząca, że, jak śpiewał Bob Dylan, „czasy nadchodzą nowe”, pozostaje ważna nie tylko dla pokoleniowych czy środowiskowych manifestów. $\mathrm{Na}$ pewno zawsze $\mathrm{w}$ jakiś sposób określa ona poszukiwania pisarzy - i te światopoglądowe, i te warsztatowe. U autorów dziewiętnastowiecznych powieści realistycznych doświadczenie granicznej zmiany decyduje o losach bohaterów, wyznacza także w pewien sposób reguły literackiej reprezentacji i organizuje porozumienie z odbiorcą. Andrzej Chwalba jako przykład „rozchodzenia się” rozpoznań polskich i zachodnich historyków podawał cezurę Wiosny Ludów, która dla tych ostatnich miała zasadnicze znaczenie jako granica wyraźnie dzieląca stary świat od rodzącej się nowoczesności ${ }^{33}$. Charakterystyczne, że do wagi tej cezury nie trzeba byłoby przekonywać Bolesława Prusa jako autora Lalki, zwłaszcza czytanej jako powieść o transformacjach nowoczesności - co potwierdza wagę literatury jako szczególnego społecznego sejsmografu. W biografiach bohaterów Lalki, których Stanisław Brzozowski trafnie nazwał ludźmi czasu wielkiej zmiany $^{34}$, uwydatniają się cezury stanowiące wyznaczniki owej metamorfozy:

${ }^{29}$ A. Świętochowski, My $i$ wy, w: idem, Wybór pism krytycznoliterackich, wybór S. Sandler, wstęp i przypisy M. Brykalska, Warszawa 1973, s. 68.

${ }^{30}$ Jest to oczywiście związane z poetyką manifestu, vide na ten temat m.in.: M. Głowiński, Trzy młodopolskie manifesty literackie, „Pamiętnik Literacki” 1995, z. 2, s. 87-104 oraz P. Czapliński, Poetyka manifestu literackiego 1918-1939, Warszawa 1997.

${ }^{31}$ A. Kluba, op. cit., s. 27.

${ }^{32}$ Stąd np. dużo bardziej przekonującym sposobem refleksji nad „przełomem” wydaje się analiza o charakterze konstelacyjnym, jak ta, którą proponują T. Budrewicz i T. Sobieraj we wstępie do antologii $W$ sprawie przełomu antypozytywistycznego. Spory krytyczne wokót „Zarysu literatury polskiej z ostatnich lat szesnastu” Piotra Chmielowskiego, seria „Polemika krytycznoliteracka w Polsce", t. 5, Poznań 2015.

${ }^{33}$ A. Chwalba, op. cit., s. 82.

${ }^{34}$ „Czuje się w psychologii postaci Prusa, w samym języku, jakim mówią one, wpływ nieustannie dokonującej się zmiany w strukturze społecznej”. S. Brzozowski, Bolesław Prus, w: idem, Wspótczesna powieść i krytyka literacka, oprac. i wstęp J. Z. Jakubowski, Warszawa 1971, s. 87. 
właśnie Wiosna Ludów, powstanie styczniowe, połowa lat siedemdziesiątych czas ustalania się pejzażu politycznego Europy po militarnej klęsce Francji i wojnie na Bałkanach. Tak wygląda historia XIX w. widziana $\mathrm{z}$ wewnętrznej perspektywy Prusa - uczestnika, świadka i obserwatora zachodzących za jego życia wydarzeń. Prusa, który, jak pisał, pochował „dawnego siebie” na polu bitwy pod Białką z roku 1863 i który w latach osiemdziesiątych XIX w. notował pogłębiające się poczucie niepewności, nie tylko to związane $\mathrm{z}$ własnymi chorobowymi ograniczeniami (jak klaustrofobia czy krótkowzroczność), ale też z określonymi wyznacznikami klimatu politycznego i społecznego. Wagę tych dat jako cezur polskiego życia drugiej połowy XIX w. i przełomu stuleci podkreślał Prus, planując swoją niedokończoną powieść Przemiany, w której chciał pokazać „prądy społeczne” w Królestwie Polskim ${ }^{35}$.

W Lalce wyraziste cezury wyznaczone przez wspomniane wydarzenia łączą ze sobą plany biografii indywidualnych i zbiorowych. Warto w tym miejscu zauważyć, że losy Wokulskiego wpisać można w koncepcje Carla Gustava Junga dotyczące rytmu egzystencji i progów wyznaczających fazy rozwoju ludzkiej osobowości. Według Junga to właśnie wejście człowieka w etap „połowy życia”, nadchodzący po czterdziestce, rozpoczyna w większości przypadków okres indywiduacji, czyli drogi ku prawdziwej dojrzałości ${ }^{36}$. Na pewno tak znaczenie tej fazy w swoim życiu postrzega bohater Prusa. Związane z tym jego przeżycia (rozchwianie emocjonalne, desperackie poszukiwanie celu, świadomość sytuacji progowej) autor po mistrzowsku splata $\mathrm{z}$ cezurą połowy lat siedemdziesiątych XIX w., kiedy dzieje się akcja powieści i z ważnym dla siebie czasem następnej dekady, którą, jak pisze o tym wielokrotnie w kronikach i innych tekstach publicystycznych, traktuje jako ważny próg historii XIX w. - próg, który może wyznaczyć drogę ku dojrzałości polskiego społeczeństwa ${ }^{37}$. Zapisem tej drogi miały być w planach Prusa „powieści z wielkich pytań epoki”, do których oczywiście sam autor zaliczał Lalkę, w porze jej tworzenia zbliżony zresztą wiekiem do Wokulskiego... Mówię o tym, bo szukanie cezur w sposób oczywisty łączy się ściśle z biografią. Narracje autobiograficzne zawsze odnotowują poszczególne fazy życia i wyznaczają ich granice. W dodatku, jak zauważa Małgorzata Czermińska, „kulturowy porządek biografii ma swą rozciągliwość

${ }^{35}$ Z. Szweykowski, „Przemiany” - niedokończona powieść Bolestawa Prusa, „Archiwum Literackie”, t. 19, Wrocław 1974, s. 65. Vide B. Prus, Notatki do nie dokończonej powieści „Przemiany”, ibidem, np. s. 87.

${ }^{36}$ Vide A. Samuels, S. Shorter, F. Plaut, Krytyczny stownik analizy Jungowskiej, thum. W. Bobecki, L. Zielińska, Wrocław 1994, s. 76-77. Vide także P. K. Oleś, Kryzys „połowy życia”interpretacja i inspiracje K.G. Junga, eneteia.pl (d.d. 1.04.2020).

${ }^{37}$ Vide E. Paczoska, Dojrzewanie, dojrzałość, niedojrzałość. Od Bolestawa Prusa do Olgi Tokarczuk, Warszawa 2004. 
dłuższą niż samo życie przeżyte, sięga bowiem w czas przed narodzinami i po śmierci. Wykracza poza oba graniczne punkty życia jednostki”; ten prolog i epilog „w sposób szczególny zakorzeniają [...] jedyne i niepowtarzalne życie jednostki w społecznym porządku wspólnoty"38. Interesująca w tym rozpoznaniu wydaje się „rozciągliwość” czasu biografii i jej wewnętrznych granic, związanych, $\mathrm{z}$ jednej strony, $\mathrm{z}$ biologicznym rytmem życia, $\mathrm{z}$ drugiej zaś $-\mathrm{z}$ jego obrazem kulturowym. Obserwacja ta w ważny dla mnie sposób substancjalizuje wyobrażenie cezury, nadając jej charakter przestrzenny, do czego jeszcze powrócę. Na pewno też łączy się ściśle z odczuciem czasowości, które to doświadczenie (w sensie indywidualnym i zbiorowym) jest, z mojej perspektywy, jednym z ważniejszych śladów pozwalających wyznaczyć jakieś granice w historii literatury. Ale oczywiście, podążając za nim, trzeba brać jednocześnie pod uwage tropy wynikające z rytmu zmian związanych z wewnętrzną perspektywą literatury, z przemianami jej autonomicznego świata.

\section{Anatomia cezury: rok 1989}

Odejdźmy na chwilę od XIX w., by spojrzeć na życie cezur w okresach i dyskursach nam czasowo bliższych. Oczywiście ustanawianie cezury w historiach literatury polskiej XIX i XX w. wiązało się przede wszystkim z datami politycznymi i wydarzeniami wielkiej historii, które decydowały o losach Polski w tych stuleciach. Kiedy historia przyspieszała, a momentów progowych jakby przybywało, dochodziło do swoistego namnażania cezur (np. mówiono o literaturze po Październiku 1956, po Marcu 1968, po Grudniu 1970 itd.). Ta praktyka budziła oczywiście zastrzeżenia historyków literatury współczesnej, choć czasem trudno im się było wyłamać z magicznego wpływu tych dat. Dziś w dziejach literatury polskiej powstającej po drugiej wojnie światowej wyróżnia się dwie silne cezury: rok 1956 i rok 1989. Chciałabym teraz przyjrzeć się tej ostatniej dacie. Biorąc pod uwagę wagę odczucia czasowości, na pewno moment transformacji ustrojowej większość Polaków postrzega dziś jako wyrazistą cezurę, wpływającą na wszystkie sfery życia i kultury. Wagę tego progu podkreślali oczywiście pisarze wchodzący wówczas w życie (jak pokolenie „brulionu”). Wzmacniały to rozpoznanie takie efektowne, choć, co dziś wiadomo, przedwczesne diagnozy, jak ogłoszenie „końca historii” przez Francisa Fukuyamę czy obwieszczenie „zmierzchu paradygmatu romantycznego" przez Marię Janion ${ }^{39}$.

${ }^{38}$ M. Czermińska, Przestrzenne odniesienia czasowych faz biografii, 2015, repozytorium uwb.edu.pl (d.d. 31.03.2020) (podkr. - aut.).

${ }^{39} \mathrm{O}$ uproszczeniach związanych $\mathrm{z}$ tego rodzaju generalizacjami vide np. T. Walas, „Zmierzch paradygmatu” - i co dalej?, w: eadem, Zrozumieć swój czas. Kultura polska po komunie rekonesans, Kraków 2003, s. 155. 
Spójrzmy jednak na funkcjonalność roku 1989 jako cezury historycznoliterackiej. W istocie, jeśli chodzi o „świat literackości”, zmieniło się wówczas bardzo wiele - były to zmiany o charakterze politycznym, ale również te związane $\mathrm{z}$ nowymi warunkami działania rynku kultury, a przede wszystkim te wynikające $\mathrm{z}$ nowego otwarcia na świat. U progu lat dziewięćdziesiątych wtargnęły do nas jednocześnie wielką falą zjawiska, które na Zachodzie czy w Stanach Zjednoczonych funkcjonowały od lat sześćdziesiątych XX w. i miały tam własny rytm rozwojowy. Spójrzmy choćby na dwa kręgi tych zjawisk. Pierwszy z nich to feminizm; warto np. przypomnieć, że w Polsce niemal jednocześnie ukazały się w latach dziewięćdziesiątych Wtasny pokój Virginii Woolf i Kobiecy eunuch Germaine Greer, książki odległe od siebie o pięćdziesiąt lat, „ikony” różnych fal feminizmu. Drugi - to gwałtowna kariera gatunków popularnych, kryminałów, ale także powieści z obszaru zwanego „chiclit” - najpierw w postaci tłumaczeń globalnych bestsellerów, a potem coraz śmielej wydawanej twórczości rodzimej.

Pytanie: co oznacza rok 1989 dla literatury polskiej? zadawali badacze już w latach dziewięćdziesiątych XX w., analizując nowe utwory powstające za sprawą „apetytu na przemianę" ${ }^{* 0}$. Oczywistość tej cezury wiązano z pojawieniem się nowych tematów i gatunków, ale także typów wrażliwości i sposobów światoodczuwania, $\mathrm{z}$ różnych względów upodrzędnianych w polskiej powojennej literaturze. Najogólniej rzecz biorąc, kamery pisarzy zostały nastawione na narracje lokalne i dotąd marginalizowane - także za sprawą wielkiej fali nowych inspiracji płynących $\mathrm{z}$ gwałtownie recypowanych obcych wzorów: powieści postmodernistycznej, utworów feministycznych czy literatury mniejszości seksualnych. Diametralnie zmieniła się sytuacja pisarza, dotąd w tradycji polskiej kultury (podtrzymywanej paradoksalnie przez władze PRL-u) pełniącego funkcję społecznego autorytetu czy sumienia. Pojawiło się całkiem nowe zjawisko pisarzy-celebrytów, konkurujących na medialnym rynku z „ekspertami” od innych specjalności interesujących dla odbiorców.

Cezura 1989 r. to dziś historycznoliteracki truizm - i trudno podważać jej znaczenie. Jej waga nie ulega wątpliwości, jeśli chodzi o literacką infrastrukturę, o kręgi inspiracji politycznych i bodźców artystycznych, które stawały się wylęgarnią nowych tematów literatury i nowych bohaterów. Czy jednak $\mathrm{w}$ istocie język literatury podążał krok w krok za tymi zmianami? Pytanie to stawia np. Marcin Jaworski w niedawno wydanej książce dotyczącej sporów o młodą poezję w latach dziewięćdziesiątych XX w. Jego zdaniem, patrząc z perspektywy następnego trzydziestolecia, trudno cezurę 1989 przyjmować bez zastrzeżeń, bo literatura w zakresie swego autonomicznego świata nie szła

\footnotetext{
${ }^{40}$ Vide J. Jarzębski, Apetyt na przemianę: notatki o prozie wspótczesnej, Kraków 1997.
} 
wcale w stronę - „wbrew ówczesnym pozorom oraz wielkim apetytom radykalnej przemiany etyki i poetyki. Rewolucji nie uległy zbiorowe ideologie wyznawane przez pisarzy ani indywidualna wrażliwość i doświadczenie opisywane w poszczególnych utworach" ${ }^{41}$. Tę obserwację potwierdzać może rozwój powieści. Mam bowiem wrażenie, że dużo wcześniej, zanim rozlała się w Polsce lat dziewięćdziesiątych fala prozy inspirowanej, najogólniej rzecz biorąc, powieścią postmodernistyczną, tworzyli pisarze wyraźnie sterujący w stronę tego modelu literatury. Myślę tu nie tylko o oczywistych przykładach Weisera Dawidka Pawła Huellego (1987) czy Pamiętnika mistycznego Małgorzaty Baranowskiej (1988), ale przede wszystkim o dużo wcześniejszych, a dziś kompletnie zapomnianych powieściach Piotra Wojciechowskiego (Kamienne pszczoły,1967, Czaszka w czaszce, 1970, Wysokie pokoje, 1977). Odnajdujemy w nich pokrewne powieści postmodernistycznej dziwaczne światy alternatywne zbudowane z powidoków Realnego, historię czytaną poprzez nieoczywiste znaki kultury (jak Muzeum Śmiecia w Wysokich pokojach), charakterystyczną mitogeografię, grę z polskim XIX w. i modernizmem - a więc to wszystko, co charakteryzować będzie np. dużo późniejsze utwory Stefana Chwina (od Hanemana, 1995).

Przypomnijmy tu jeszcze kolejną oczywistość. Filozofowie kultury i historycy literatury chętnie wytyczali granice między modernizmem a postmodernizmem, nowoczesnością a postnowoczesnością, ale potem wielu z nich doszło do wniosku, że akcentowanie gestu zerwania mistyfikowało obraz przemian kultury. Myślę tu np. o rozpoznaniach Zygmunta Baumana zapisanych już w nowym stuleciu, w których podkreślał, inaczej niż wcześniej, że ponowoczesność jest częścią nowoczesności ${ }^{42}$. Przywoływany już przeze mnie Agamben podkreślał, że kultura powstająca w orbicie powidoków i ech modernizmu ma charakter dekadencki, zatem nie może już, choćby chciała, wytworzyć funkcjonalnego dla siebie pojęcia epoki ${ }^{43}$. Sąd ten wzmacnia przydatność kategorii modernizmu jako formacji intelektualnej i literackiej o wyjątkowo długim czasie oddziaływania. Jeśli całą literaturę, również polską, umiejscowimy w obrębie formacji modernistycznej, to rok 1989 stanie się tylko jedną z wielu cezur wewnętrznych - takich, które określają warunki życia literackiego, odczucie czasowości pisarzy, związki życia artystycznego i polityki, ale nie wyznaczają najważniejszych przemian języka literatury. Funkcjonalność roku 1989 jako cezury historycznoliterackiej zależy zatem od miejsca, z którego ją obserwujemy.

\footnotetext{
${ }^{41}$ M. Jaworski, Barbarzyńcy, klasycyści i inni. Spory o młoda poezję w latach 90., Poznań 2018.

${ }^{42}$ Vide Z. Bauman, Plynna nowoczesność, tłum. T. Kunz, Warszawa 2006.

${ }^{43}$ Ibidem, s. 97-100.
} 


\section{Cezury i media}

Może więc, z punktu widzenia języka literatury, popełniamy błąd, przywiązując się do historycznoliterackiej wagi tego progu? Bo, zgodnie z polską tradycją, jesteśmy po prostu uzależnieni od kojarzenia dat historii politycznej z przemianami artystycznymi? Bo chcielibyśmy uwierzyć, że w istocie narodziła się nowa epoka - ważna dla kultury polskiej, ale także całego regionu Europy Środkowo-Wschodniej? Czy można wskazać inną cezurę, która lepiej określiłaby miejsce i sens literackiej zmiany? Może trzeba jej szukać poza kalendarzem historycznym czy politycznym?

Na pewno wyznacznikiem granic w historii kultury, także polskiej, ostatnich dekad jest pojawienie się nowych mediów, które zmieniły sytuację słowa i w pewnym sensie na nowo określiły relację między autorem a czytelnikiem. I to zmieniły w sensie globalnym, co pozwala nam znów, podobnie jak w przypadku modernizmu, cezury związane z kulturą polską włączyć w rytm przemian światowych. Może więc to nie rok 1989 mógłby wykreślać granicę nowej epoki, lecz np. 1987, kiedy w Ameryce pojawia się pierwsza powieść hipertekstowa Michaela Joyce'a afternoon. the story? Albo np. czas pojawienia się blogów, także literackich, daty premiery smartfona firmy Apple czy otwarcia mediów społecznościowych takich jak Facebook albo rozmaitych nowych komunikatorów? Truizmem jest stwierdzenie, że sieciowa rzeczywistość wywarła olbrzymi wpływ także na życie artystyczne ostatnich dekad - może w istocie kończąc erę literatury jako naczelnego medium kultury. Mówią o tym teoretycy zajmujący się przemianami rzeczywistości tekstowej $\mathrm{w}$ dobie internetu ${ }^{44}$ oraz badacze, którzy analizują „,archeologię mediów” ${ }^{45}$, a także autorzy zajmujący się zjawiskami kultury wizualnej.

$\mathrm{Z}$ ich punktu widzenia najważniejsze przemiany literatury pod wpływem nowych mediów rozpoczęły się w Polsce pod koniec pierwszej dekady XXI w. i być może miały one bardziej wyraziste konsekwencje dla polskiego „świata literackości" niż cezura roku 1989. Ponieważ pytałam wcześniej o odczucie czasowości artykułowane przez pisarzy, posłużę się tu podpowiedzią twórcy Lodu. W wydanej w 2018 r. książce Po piśmie Jacek Dukaj (rocznik 1974) stawia diagnozę kulturze i literaturze współczesnej, która mogłaby posłużyć jako wyznacznik ważnej cezury historycznoliterackiej. Diagnozę tę wyprowadza z rozpoznania, że oto na naszych oczach kończy się „,epoka pisma”, rozpoczyna - epoka „bezpośredniego transferu przeżyć” ${ }^{46}$. W epoce „człowieka postpiśmiennego"

${ }^{44}$ Warto tu wskazać też ważną publikację na temat zmian rzeczywistości tekstowej w epoce internetu: Tekst (w) sieci. 1. Tekst, język, gatunki, red. D. Ulicka, Warszawa 2009.

${ }^{45}$ Vide tak zatytułowany numer „Tekstów Drugich” z roku 2014 (z. 2), np. ibidem: M. Maryl, Fonograf Abrahama - w stronę archeologii literatury.

${ }^{46}$ J. Dukaj, Po piśmie, Warszawa 2019. 
gwałtownej zmianie ulega religia (tracąca prawomocność opartą na piśmie), filozofia (dziś, jak pisze Dukaj, to praktyka realizowana przez „bycie”, a nie pismo), polityka (w której obserwujemy postpiśmienne równouprawnienie prawdy i fałszu), w końcu ekonomia. Literatura, zdaniem autora, żeby jakoś istnieć, choćby na marginesie, musi po prostu zaakceptować konsekwencje tej wielkiej metamorfozy kultury. Argumenty Dukaja można przyjąć albo nie, choć wiele jego obserwacji wydaje się trafnych - wagę tej diagnozy jako wyznacznika cezur w przyszłej historii literatury może potwierdzić tylko czas.

Znaczenie perspektywy medialnej pokazuje też historia literatury XIX w. bo przecież i tamci nowocześni mieli swoje „nowe media” i widzieli ich wpływ na swoje życie, kulturę i komunikację społeczną. Ważną w historii literatury cezure przełomu XIX i XX w., czas krystalizacji tendencji modernistycznych i modernizacyjnych na pewno można wiązać z rozwojem technologii służących reprezentacji, np. $\mathrm{z}$ upowszechnieniem się fotografii (także jako pomocy dla literatów, bo tak traktował robienie zdjęć np. Prus), ze zmianą epoki „żywych obrazów" czy popularnych panoram na erę kina, z narodzinami nowoczesnej prasy (i np. zjawiska prasowej walki politycznej, które obserwujemy na ziemiach polskich w okresie rewolucji 1905 r.), a nawet z przestawianiem się pisarzy z pisma ręcznego na pisanie na maszynie. Wszystkie te fenomeny kultury wydają mi się dużo ważniejsze dla definiowania cezur historycznoliterackich niż np., także skądinąd istotna, data wydania przez Kazimierza Przerwę-Tetmajera I serii Poezji, który to fakt w tradycji historycznoliterackiej traktowany był jako „początek” epoki Młodej Polski (a może i polskiego modernizmu w ogóle).

\section{Cezura jako most}

Mówiąc o tradycyjnych syntezach, warto podkreślić, że utrwalony w nich model historycznoliterackich cezur wciąż miewa się dobrze. Cezur „żywot twardy” (żeby posłużyć się znaną formułą Janusza Tazbira) potwierdza np. ostatnio wydana Historia literatury polskiej Anny Nasiłowskiej (2019). Autorka, wbrew znajdującym się we wstępie deklaracjom, wykorzystuje najbardziej stereotypową siatkę temporalną, która w jej mniemaniu dobrze służy nowoczesnemu przedstawieniu dziejów naszego piśmiennictwa obcokrajowcom, dla których przeznaczona jest jej książka. Syntezę Nasiłowskiej, nie tylko zresztą z tego względu, uważam za straconą szansę zaprezentowania historii literatury polskiej w sposób wykorzystujący perspektywy, o których tu pisałam. Optykę tę wprowadzają w tej książce wyłącznie „ciekawostki” czy anegdoty, które nie osłabiają jednak wrażenia anachroniczności i stereotypowości tego ujęcia.

Jak bowiem wynika $\mathrm{z}$ analizowanych powyżej przykładów, nawet posługując się wyobrażeniem „epoki literackiej” o wyrazistych cezurach, warto uzgadniać je $\mathrm{z}$ dużo fortunniejszą dla badań kulturowych perspektywą formacji, która osłabia 
znaczenie dat granicznych, rozciągając je w czasie. Sens stosowalności cezur w praktyce historycznoliterackiej, jak dowodziłam, zależy od różnych wyznaczników, które tu w dużym skrócie przedstawiłam. Takie wyznaczniki, jak odczucie czasowości, geografia, język mediów, na równi z tradycyjnie stosowanymi (jak sytuacja polityczna, wydarzenia historyczne, związki biografii indywidualnych i zbiorowych) pozwalają wskazywać wewnętrzne granice formacji oraz progi pisarskich doświadczeń. Taki sposób myślenia „rozciaga” i substancjalizuje kategorię cezury. Pozwala ją widzieć nie jako graniczną bramkę (tu się kończy „romantyzm” i zaczyna ,pozytywizm”) czy punkt kontroli paszportowej, lecz - jako most. Ta ostatnia metafora może najlepiej określa wyobrażenie funkcjonalności kategorii granicznych w praktyce historycznoliterackiej. Most łączy dwa oddalone od siebie brzegi, które mają swoją własną lokalizacyjną tożsamość. Most ma także swoją odmienną temporalność zależną od tempa czy środka komunikacji, jakim się przemieszczamy. Możemy po nim przemknąć „ekstrapocztą” (jak się mówiło w XIX w.), ale możemy też przemieszczać się po nim powoli, obserwując z jego perspektywy oba brzegi. A tego typu uważność na pewno służy historii literatury - a przede wszystkim samej literaturze.

\section{Bibliografia}

Agamben, Giorgio, Idea prozy, tłum. i posłowie E. Górniak-Morgan, komentarz A. Serafin, Warszawa 2018.

Bauman, Zygmunt, Płynna nowoczesność, tłum. T. Kunz, Warszawa 2006.

Bolecki, Włodzimierz, Modalności modernizmu. Studia, analizy, interpretacje, Warszawa 2012.

Borkowska, Grażyna, O historii literatury polskiej w kontekście nie tylko polskim. Kilka pytań, co nie nowe, w: Polonistyka na początku XXI wieku. Diagnozy, koncepcje, perspektywy. Materiały VI Światowego Kongresu Polonistów, Katowice 2016.

Brzozowski, Stanisław, Bolesław Prus, w: idem, Współczesna powieść i krytyka literacka, oprac. i wstęp J. Z. Jakubowski, Warszawa 1971.

Budrewicz, Tadeusz, Sobieraj, Tomasz, Wstę, w: W sprawie przełomu antypozytywistycznego. Spory krytyczne wokót „Zarysu literatury polskiej z ostatnich lat szesnastu” Piotra Chmielowskiego, seria „Polemika krytycznoliteracka w Polsce”, t. 5, Poznań 2015.

Chmielowski, Piotr, Zarys literatury polskiej z ostatnich lat szesnastu, Wilno 1881.

Chwalba, Andrzej, Metodologiczne aspekty badań nad historia Polski w XIX wieku, „PAU. Prace Komisji Historii Nauki” 2004, t. 6.

Cieślak-Sokołowski, Tomasz, Nowe modernizmy. Mapa debat, „Poznańskie Studia Polonistyczne”, Seria Literacka 24 (44): Odnawianie modernizmu, Poznań 2014.

Czapliński, Przemysław, Poetyka manifestu literackiego 1918-1939, Warszawa 1997.

Czermińska, Małgorzata, Przestrzenne odniesienia czasowych faz biografii, 2015, repozytorium uwb.edu.pl (d.d. 31.03.2020). 
Domańska, Ewa, Mikrohistorie. Spotkania w międzyświatach, Poznań 1999.

Dukaj, Jacek, Po piśmie, Warszawa 2019.

Gloger, Maciej, Pozytywizm: między nowoczesnościa a modernizmem, „Pamiętnik Literacki” 2007, z. 1.

Głowiński, Michał, Trzy młodopolskie manifesty literackie, „Pamiętnik Literacki” 1995, z. 2.

Jarzębski, Jerzy, Apetyt na przemianę notatki o prozie wspótczesnej, Kraków 1997.

Jaworski, Marcin, Barbarzyńcy, klasycyści i inni. Spory o młoda poezję w latach 90., Poznań 2018.

Kluba, Agnieszka, Autoteliczność - referencyjność - niewyrażalność. O nowoczesnej poezji polskiej (1918-1939), Wrocław 2004.

Kowalczykowa, Alina, Wiek XIX: przełomy, cezury, płynność, w: Wiedza o literaturze i edukacja. Księga referatów Zjazdu Polonistów Warszawa 1995, red. T. Michałowska, Z. Goliński, Z. Jarosiński, Warszawa 1996.

Kunz, Tomasz, Nowa historia literatury - bez dogmatu $i$ bez przedmiotu?, „Ruch Literacki" 2011, z. 6.

Literatura i kultura lat 60. XIX wieku między polityka a prywatnościa. Dyslokacje, red. U. Kowalczuk, D. W. Makuch, D. M. Osiński, Warszawa 2019.

Maciejewski, Janusz, Miejsce pozytywizmu polskiego w XIX-wiecznej formacji kulturowej, w: Pozytywizm. Języki epoki, red. G. Borkowska, J. Maciejewski, Warszawa 2001.

Maciejewski, Janusz, Przedburzowcy. Z problematyki przełomu między romantyzm a pozytywizmem, Kraków 1973.

Maj, Joanna, Nowe historie literatury polskiej - metodologiczny rekonesans, w: Polonistyka na początku XXI wieku. Diagnozy, koncepcje, perspektywy. Materiaty VI Światowego Kongresu Polonistów, Katowice 2016.

Majewski, Tomasz, Modernizmy i ich losy, w: Rekonfiguracje modernizmu. Nowoczesność i kultura popularna, red. idem, Warszawa 2009.

Maryl, Maciej, Fonograf Abrahama - w stronę archeologii literatury, „Teksty Drugie” 2014, z. 2.

Nycz, Ryszard, Język modernizmu. Prolegomena historycznoliterackie, Warszawa 1997.

Oleś, Piotr K., Kryzys „połowy życia” - interpretacja i inspiracje K.G. Junga, eneteia.pl (d.d. 1.04.2020).

Paczoska, Ewa, Dojrzewanie, dojrzałość, niedojrzałość. Od Bolesława Prusa do Olgi Tokarczuk, Warszawa 2004.

Paczoska, Ewa, Młoda Polska i mapy modernizmu, w: Młoda Polska $w$ najnowszych badaniach, red. E. Jakiel, T. Linkner, Gdańsk 2016.

Paczoska, Ewa, Słowo wstępne, w: eadem, Prawdziwy koniec XIX wieku. Śladami nowoczesności, Warszawa 2010.

Paczoska, Ewa, Wstęp, w: Problemy literatury i kultury modernizmu w Europie Środkowo-Wschodniej, t. 1: Teksty doświadczenia, red. E. Paczoska, I. Poniatowska, M. Chmurski, Warszawa 2017.

Płachecki, Marian, Dekadentyzm południa wieku: rekonesans, „Studia Filologiczne Akademii Świętokrzyskiej” 2002, t. 17.

Prus, Bolesław, Notatki do nie dokończonej powieści „Przemiany”, „Archiwum Literackie", t. 19, Wrocław 1974. 
Przybylski, Ryszard, Klasycyzm, czyli prawdziwy koniec Królestwa Polskiego, Warszawa 1983.

Samuels, Andrew, Shorter, Bani, Plaut, Fred, Krytyczny stownik analizy Jungowskiej, tłum. W. Bobecki, L. Zielińska, Wrocław 1994.

Sosnowska, Danuta, Czeski przełom modernistyczny a kondensacja czasu kulturowego, „Przegląd Filozoficzno-Literacki” 2013, nr 1-2: Modernizm(y) Europy Środkowo-Wschodniej.

Szweykowski, Zygmunt, „Przemiany” - niedokończona powieść Bolesława Prusa, „Archiwum Literackie", t. 19, Wrocław 1974.

Świętochowski, Aleksander, My $i$ wy, w: idem, Wybór pism krytycznoliterackich, wybór S. Sandler, wstęp i przypisy M. Brykalska, Warszawa 1973.

Tarkowska, Elżbieta, Czas w życiu Polaków: wyniki badań, hipotezy, impresje, Warszawa 1992.

Tekst (w) sieci. 1. Tekst, język, gatunki, red. D. Ulicka, Warszawa 2009.

Walas, Teresa, Czy jest możliwa inna historia literatury?, Kraków 1993.

Walas, Teresa, „Inna historia literatury jest możliwa”. Rozmowa z Teresa Walas przeprowadzona przez Agnieszkę Wnuk i Tomasza Mackiewicza, ,Tekstualia” 2010, nr 3.

Walas, Teresa, „Niebyta” historia literatury, w: Narracja i tożsamość, t. 2: Antropologiczne problemy literatury, red. R. Nycz, W. Bolecki, Warszawa 2004.

Walas, Teresa, „Zmierzch paradygmatu” - i co dalej?, w: eadem, Zrozumieć swój czas. Kultura polska po komunie - rekonesans, Kraków 2003.

Witkowska, Alina, Wielkie stulecie Polaków, Warszawa 1987.

Żmigrodzka, Maria, Polska powieść biedermeierowska, „Pamiętnik Literacki” 1966, z. 2.

EWA PaCzoska, historyk literatury polskiej drugiej połowy XIX i XX w., profesor na Wydziale Polonistyki UW. Opublikowała m.in. książki autorskie: Lalka czyli rozpad świata (1995, 2 wyd. 2008), Dojrzewanie, dojrzatość, niedojrzatość. Od Bolestawa Prusa do Olgi Tokarczuk (2004), Prawdziwy koniec XIX wieku. Śladami nowoczesności (2010), Lekcje uważności. Moderniści i realizm (2018). Redaktorka wielu tomów zbiorowych, ostatnio m.in.: Wiktorianie nad Tamiza i nad Wista (2016), Problemy literatury i kultury modernizmu w Europie Środkowo-Wschodniej (1867-1918), t. 1-3 (2017), Modernizmy Europy Środkowo-Wschodniej. Coraz szersze marginesy (2020). 